\title{
IMPLEMENTASI OPEN ENDED PROBLEM DALAM MATA KULIAH STATISTIK UNTUK MENINGKATKAN KEMAMPUAN PEMECAHAN MASALAH PADA MAHASISWA MANAJEMEN FOOD AND BAVERAGE SEKOLAH TINGGI PARIWISATA TRIATMA JAYA
}

\author{
Laras Oktaviani, Nirmala Tari \\ STIE Triatma Mulya, Akademi Komunitas MAPINDO \\ larasoktaviani999@gmail.com, nirmalatari23@yahoo.com
}

\begin{abstract}
This classroom action research aims at improving statistical problem solving ability through the implementation of open ended problems in the students of MFB E semester VI STIPAR Triatma Jaya in the academic year 2016/2017. The design of this research is Classroom Action Research in which subject was student MFB E semester VI STIPAR Triatma Jaya consisted of 25 students. Data of problem solving ability were collected by using a problem-solving test in the form of essay test. Data of problem solving abilities were analyzed quantitatively. The results of this study show that: (1) implementation of open ended problem can improve the statistical problem solving ability of student MFB E semester VI STIPAR Triatma Jaya year lesson 2016/2017. In cycle I, the students' average problem solving ability reached 70.28, whereas in cycle II the average value of problem solving ability was successfully increased into 80.08. These results indicate that there has been an increasing in the average score of problem-solving abilities by 9.8 from cycle I to cycle II. (2) Implementation of open ended problem can improve students' statistics learning mastery MFB E semester VI STIPAR Triatma Jaya year lesson 2016/2017. In cycle I the percentage of mastery was $68 \%$, while in cycle II the percentage of learning mastery was successfully increased to $88 \%$. These results indicate that there has been an increasing in percentage mastery learning by $20 \%$ from cycle I to cycle II.
\end{abstract}

Keywords: open ended problem, statistical problem solving ability

\section{A. PENDAhuluan}

Undang-Undang Republik Indonesia Nomor 20 tahun 2003 tentang Sistem Pendidikan Nasional mengamanatkan bahwa sistem pendidikan nasional harus mampu menjamin mutu serta relevansi dan efisiensi manajemen pendidikan dalam upaya menghadapi tantangan sesuai dengan tuntutan perubahan kehidupan lokal, nasional demi keperluan dirinya, masyarakat, bangsa dan negara. Sistem pendidikan nasional penting artinya karena memberi kesadaran kepada masyarakat bahwa tanggungjawab perbaikan pendidikan bukan hanya terletak pada pundak pemerintah, melainkan menjadi tanggung jawab masyarakat.

Berbicara soal pendidikan, tidak terlepas dari proses belajar mengajar di kelas. Belajar pada hakikatnya adalah proses interaksi terhadap semua situasi yang ada di sekitar individu (Slameto, 2003). Proses belajar mengajar di kelas bagi peserta didik tidak selamanya berlangsung secara normal. Terkadang mereka merasa senang mengikuti pembelajaran dan terkadang merasa bosan. Dalam hal ini peserta didik dapat memiliki semangat belajar yang tinggi, akan tetapi kadang bisa juga menjadi rendah. Demikianlah realita yang sering dihadapi oleh guru pada saat proses belajar mengajar di dalam kelas. Baik tidaknya hasil proses pembelajaran dapat dilihat dan dirasakan oleh pendidik dan peserta didik sendiri.

Menurut paradigma kontruktivisme, belajar adalah proses menginternalisasi, 
membentuk kembali atau membentuk baru pengetahuan (Mudjiman, 2007). Implikasi pandangan ini dalam proses pembelajaran adalah bahwa pengetahuan tidak dapat dipindahkan secara utuh dari pikiran guru ke pikiran siswa. Pengetahuan yang diperoleh siswa merupakan hasil kontruksinya sendiri dari gagasan-gagasan yang telah dimilikinya dengan gagasan yang masuk dari luar dirinya (Suparno, 1997). Melalui aktivitas belajar tersebut diharapkan dapat meningkatkan pengalaman belajar sehingga proses pembelajaran akan menjadi lebih bermakna bagi siswa.

Peran pendidik sangat penting untuk mendapatkan pembelajaran yang berkualitas. Maka dari itu, inovasi-inovasi dalam pembelajaran sangat diperlukan untuk meningkatkan kualitas lulusan Sumber Daya Manusia (SDM). Inovasi-inovasi pembelajaran tidak hanya diperlukan di jenjang SD, SMP, dan SMA saja, tetapi juga di perguruan tinggi. Dosen memegang peranan yang sangat penting dalam proses perkuliahan di perguruan tinggi. Mengajar mahasiswa kelihatannya memang mudah, akan tetapi juga diperlukan penggunaan pendekatan pembelajaran yang inovatif. Tidak semua mata kuliah disukai oleh mahasiswa. Apalagi jika mata kuliah tersebut berkaitan dengan hitung-hitungan, seperti statistik.

Mata kuliah statistik merupakan salah satu mata kuliah yang diajarkan di perguruan tinggi. Mata kuliah ini biasanya jarang digemari karena berkaitan dengan hitunghitungan. Padahal mata kuliah statistik sangat diperlukan dalam penyusunan tugas akhir maupun skripsi. Dengan adanya mata kuliah ini, diharapkan dapat membantu mahasiswa menangani informasi yang bersifat kuantitatif. Sebagai calon ilmuwan, mahasiswa diharapkan memiliki kemampuan dalam menggunakan pendekatan ilmiah dalam memecahkan masalah. Penelitian akademis seperti yang diterapkan dalam penulisan skripsi adalah salah satu kegiatan keilmuan dimana permasalahan yang ada dipecahkan dengan melalui penggunaan pendekatan ilmiah.
Dalam memecahkan permasalahan maka statsitik dapat berperan sebagai alat bantu yang dapat digunakan untuk menangani data-data kuantitatif yang diperoleh dalam penelitian. Dengan kata lain, melalui analisis statistik, dapat digambarkan situasi, kondisi, atau fakta yang diteliti dan sekaligus dapat diperoleh suatu kesimpulan yang masuk akal.

Saat ini masih banyak dosen-dosen yang mengajar statistik dengan pendekatan close problem. Hal ini terlihat pada perkuliahan statistik di STIPAR Triatma Jaya. Berdasarkan observasi awal yang dilakukan, soal-soal yang diberikan dosen pada saat perkuliahan bersifat close problem. Dimana dalam menyelesaikan permasalahan statistik tertutup ini, prosedur yang digunakannya sudah hampir bisa dikatakan standar alias baku. Akibatnya timbul persepsi yang agak keliru terhadap statistik. Statistik dianggap sebagai pengetahuan yang pasti dan prosedural. Sementara itu, masalah-masalah statistik terbuka (open problems) sendiri hampir tidak tersentuh, hampir tidak pernah muncul dan disajikan dalam proses pembelajaran statistik di kelas. Akibatnya bila ada permasalahan statistik macam ini, soal atau permasalahan itu dianggap 'salah soal' atau soal yang tidak lengkap.

Penggunaan close problem dalam perkuliahan statistik secara terus menerus, akan berdampak pada kemampuan pemecahan masalah mahasiswa. Kreativitas mahasiswa kurang terlatih dalam menjawab soal. Mahasiswa hanya mengingat prosedur baku saja dalam menyelesaikan suatu masalah, artinya mereka hanya menghafalkan prosedur menjawab seperti biasanya. Padahal dalam mata kuliah statistik, kemampuan pemecahan masalah mahasiswa sangat diperlukan.

Kemampuan pemecahan masalah adalah suatu tindakan untuk menyelesaikan masalah atau proses yang 
menggunakan kekuatan dan manfaat matematika dalam menyelesaikan masalah, yang juga merupakan metode penemuan solusi melalui tahap-tahap pemecahan masalah (Suherman, 2003). Kemampuan pemecahan masalah merupakan tujuan umum dalam perkuliahan statistik, bahkan sebagai jantungnya statistik, artinya kemampuan pemecahan masalah merupakan kemampuan dasar dalam kuliah statistik. Dengan membiasakan mahasiswa untuk menyelesaikan masalah, memungkinkan mahasiswa itu menjadi lebih analitis dalam mengambil keputusan dalam kehidupannya.

Berdasarkan permasalahan di atas, maka perlu dilakukan perbaikan dalam perkuliahan statistik. Dosen di dalam melaksanakan perkuliahan, harus bisa memilih maupun menetapkan suatu pendekatan pembelajaran yang tepat di kelas sehingga hasil pembelajaran lebih optimal. Salah satu pendekatan pembelajaran yang dapat meningkatkan kemampuan pemecahan masalah adalah pendekatan Open-ended Problem. Pendekatan openended problem adalah pendekatan pembelajaran yang menyajikan suatu permasalahan yang memiliki metode atau penyelesaian yang benar lebih dari satu. Menurut Suherman, dkk (2003) problem yang diformulasikan memiliki multi jawaban yang benar disebut problem tak lengkap atau disebut juga open ended problem atau soal terbuka. Pembelajaran dengan pendekatan Open Ended Problem diawali dengan memberikan masalah terbuka kepada siswa. Kegiatan pembelajaran harus mengarah dan membawa siswa dalam menjawab masalah dengan banyak cara serta mungkin juga dengan banyak jawaban (yang benar), sehingga merangsang kemampuan intelektual dan pengalaman siswa dalam proses menemukan sesuatu yang baru.

Menurut Shimada \& Becker (Murni, 2013) pendekatan open-ended problem memberikan kesempatan kepada mahasiswa untuk menginvestigasi berbagai strategi dan cara yang diyakininya sesuai dengan mengelaborasi permasalahan. Tujuannya agar kemampuan berpikir mahasiswa dapat berkembang secara maksimal dan pada saat yang sama kegiatan-kegiatan kreatif dari setiap siswa dapat terkomunikasikan melalui proses belajar mengajar. Pokok pikiran dari pembelajaran dengan open-ended problem yaitu pembelajaran yang membangun kegiatan interaktif pada mahasiswa sehingga mengundang mahasiswa untuk menjawab permasalahan melalui berbagai strategi. Dengan kata lain pembelajaran dengan pendekatan open-ended problem bersifat terbuka.

Bingolbali (2011) menyatakan bahwa masalah yang mengundang lebih dari satu jawaban benar atau bersifat open-ended problem mampu meningkatkan aktivitas siswa saat pembelajaran. Secara tidak langsung, ini akan meningkatkan kemampuan komunikasi siswa. Ketika siswa mampu mengomunikasikan ide-ide matematisnya, itu berarti ia sudah memahami konsep statistik sepenuhnya. Pehkonen (1999) menyatakan bahwa open-ended problem membebaskan siswa dalam proses penyelesaian masalah yang berarti siswa akan berakhir dengan jawaban-jawaban yang berbeda dimana semua jawaban tersebut samasama bersifat benar sehingga siswa mendapat kesempatan untuk meningkatkan kemampuan kreatif mereka. Oleh karena itu hal yang perlu diperhatikan adalah kebebasan mahasiswa untuk berpikir dalam membuat progres pemecahan sesuai dengan kemampuan, sikap, dan minatnya sehingga pada akhirnya akan dapat meningkatkan kemampuan pemecahan masalah siswa.

Dalam pembelajaran statistik, penerapan open-ended problem dimulai dengan memberikan soal yang memiliki banyak pemecahan. Mahasiswa diminta mengembangkan metode, cara, atau pendekatan yang berbeda dalam menjawab permasalahan yang diberikan 
dan bukan berorientasi pada jawaban (hasil) akhir. Mahasiswa diharapkan memiliki tujuan utama bukan untuk mendapatkan jawaban tetapi lebih menekankan pada cara bagaimana sampai pada satu jawaban. Dengan demikian tidak hanya ada satu cara dalam memperoleh jawaban, namun beberapa atau banyak.

Berdasarkan latar belakang tersebut rumusan permasalahan dari penelitian ini adalah sebagai berikut. Pertama, apakah implementasi open ended problem dalam mata kuliah statistik dapat meningkatkan kemampuan pemecahan masalah pada mahasiswa MFB E semester VI STIPAR Triatma Jaya tahun pelajaran 2016/2017? Kedua, apakah implementasi open ended problem dalam mata kuliah statistik dapat meningkatkan ketuntasan belajar pada mahasiswa MFB E semester VI STIPAR Triatma Jaya tahun pelajaran 2016/2017? Dari permasalahan tersebut, maka tujuan dari penelitian ini adalah sebagai berikut. Pertama, untuk meningkatkan kemampuan pemecahan masalah melalui implementasi open ended problem dalam mata kuliah statistik pada mahasiswa MFB E semester VI STIPAR Triatma Jaya tahun pelajaran 2016/2017. Kedua, untuk meningkatkan ketuntasan belajar melalui implementasi open ended problem dalam mata kuliah statistik pada mahasiswa MFB E semester VI STIPAR Triatma Jaya tahun pelajaran 2016/2017.

\section{B. KAJIAN LITERATUR}

\section{Open Ended Problem}

Menurut Hino (2007) masalah terbuka (open-ended problem) adalah suatu masalah yang diformulasikan sedemikian sehingga memiliki beberapa jawaban yang benar. Selanjutnya, Nohda (2000) berpendapat bahwa pendekatan open-ended sangat penting bagi setiap siswa untuk memiliki kebebasan dalam meningkatkan kemampuan pemecahan masalah sesuai dengan tingkat kemampuan dan minat mereka. Strong (2009) menyimpulkan bahwa penerapan pendekatan open-ended pada siswa menumbuhkan sikap positif siswa terhadap matematika, meningkatkan keterampilan kemampuan pemecahan masalah serta menolong siswa untuk lebih percaya diri dan berprestasi dalam matematika.

Menurut Shimada \& Becker (Murni, 2013) pendekatan openended problem memberikan kesempatan kepada mahasiswa untuk menginvestigasi berbagai strategi dan cara yang diyakininya sesuai dengan mengelaborasi permasalahan. Bingolbali (2011) menyatakan bahwa masalah yang mengundang lebih dari satu jawaban benar atau bersifat open-ended problem mampu meningkatkan aktivitas siswa saat pembelajaran. Secara tidak langsung, ini akan meningkatkan kemampuan komunikasi siswa.

\section{Kemampuan Pemecahan Masalah}

Pemecahan masalah menurut Winarni dan Harmini (2011) didefinisikan sebagai suatu proses penerimaan tantangan dan kerja keras untuk menyelesaikan suatu masalah. Kemampuan pemecahan masalah adalah suatu tindakan untuk menyelesaikan masalah atau proses yang menggunakan kekuatan dan manfaat matematika dalam menyelesaikan masalah, yang juga merupakan metode penemuan solusi melalui tahap-tahap pemecahan masalah (Suherman, 2003). Standar NCTM Tahun 2000 menyebutkan pemecahan masalah merupakan esensi dari daya matematik (mathematical power), dan pemecahan masalah hampir sama dengan melakukan matematika (doing mathematics).

Usman (2014) menyatakan bahwa pemecahan masalah merupakan salah satu kompetensi yang menjadi fokus dalam pemebelajaran matematika. Menurut 
Polya (Wardhani, dkk, 2010) strategi dalam pemecahan masalah terdiri atas empat langkah yaitu memahami masalah, membuat rencana pemecahan masalah, melaksanakan rencana pemecahan masalah, dan membuat review atas pelaksanaan rencana pemecahan masalah.

\section{METODE PENELITIAN}

Penelitian ini merupakan penelitian tindakan kelas (Classroom Action Research) yang dilakukan di Sekolah Tinggi Pariwisata Triatma Jaya yang berlokasi di Dalung, KutaBali tahun pelajaran 2016/2017. Penelitian ini dilaksanakan selama kurang lebih 3 bulan, yaitu dari bulan Februari sampai April 2017.

Subjek penelitian tindakan ini adalah mahasiswa MFB kelas E semester VI STIPAR Triatma Jaya pada tahun pelajaran 2016/2017, yang berjumlah 25 orang. Objek penelitian tindakan ini adalah kemampuan pemecahan masalah statistik mahasiswa MFB kelas E semester VI STIPAR Triatma Jaya tahun pelajaran 2016/2017 yang ditandai dengan nilai rata-rata ujian akhir. Kemampuan pemecahan masalah yang diukur meliputi tiga dimensi, yaitu: memahami masalah, menyelesaikan masalah, dan menjawab masalah. Adapun indikator dari dimensi memahami masalah, meliputi kemampuan mengidentifikasi kecukupan data untuk memecahkan masalah dan membuat model matematik dari suatu situasi atau masalah sehari-hari. Indikator dari dimensi menyelesaikan masalah, meliputi kemampuan memilih dan menerapkan strategi untuk menyelesaikan model atau masalah statistik dan atau di luar statistic, dan menerapkan statistik secara bermakna. Indikator dari dimensi menjawab masalah, meliputi kemampuan menjelaskan atau menginterpretasikan hasil sesuai permasalahan asal, serta memeriksa kebenaran hasil atau jawaban.

Tahapan-tahapan dari penelitian ini terdiri dari beberapa siklus. Dimana setiap siklus terdiri dari empat langkah, yaitu: (1) perencanaan, (2) pelaksanaan tindakan, (3) observasi, dan (4) refleksi. Pada tahap perencanaan, yang dilakukan yaitu menyusun jadwal penelitian, mempersiapkan Rencana Pembelajaran Semester (RPS), merancang materi pembelajaran sesuai dengan bahan kajian yang dipilih yaitu penyajian data, ukuran pusat dan ukuran letak, menyusun soal tes akhir siklus I beserta pedoman penilaiannya. Pada tahap pelaksanaan tindakan yang dilakukan adalah mengimplementasikan openended problem dalam pembelajaran statistik. Pada tahap observasi, yang dilakukan adalah mengamati perilaku mahasiswa selama proses pembelajaran dan mencatat kemajuankemajuan mahasiswa serta kendala yang dihadapi. Pada tahap refleksi, yang dilakukan adalah mengkaji, melihat, dan mempertimbangkan hasil atau dampak tindakan dari berbagai kriteria. Berdasarkan hasil refleksi tersebut maka dilakukan perbaikan terhadap proses pembelajaran selanjutnya. Data kemampuan pemecahan masalah diperoleh melalui tes kemampuan pemecahan masalah yang diberikan di akhir setiap siklus. Tes kemampuan pemecahan masalah statistik berupa tes uraian yang terdiri dari 5 butir pertanyaan.

Teknik analisis data yang digunakan adalah analisis statistik deskriptif yaitu statistik yang tingkat pekerjaannya mencakup cara-cara menghimpun, menyusun, mengolah, menyajikan, dan menganalisa data angka, agar dapat memberikan gambaran yang teratur, ringkas, dan jelas mengenai suatu gejala, sehingga dapat ditarik pengertian atau makna tertentu. Keberhasilan proses pembelajaran ditentukan pada pencapaian penguasaan materi minimal 70 dengan persentase ketuntasan belajar minimal $85 \%$.

\section{HASIL DAN PEMBAHASAN}


Berdasarkan hasil analisis data maka disajikan pada Tabel 1 berikut. diperoleh ringkasan hasil perhitungan yang

Tabel 1

Ringkasan Hasil Analisis Data Kemampuan Pemecahan Masalah Mahasiswa MFB E Semester VI STIPAR Triatma Jaya

\begin{tabular}{|c|c|c|}
\hline 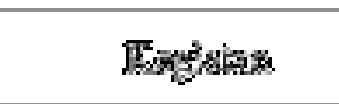 & 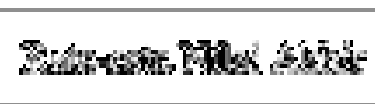 & 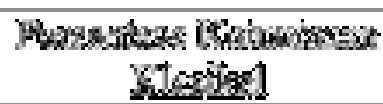 \\
\hline 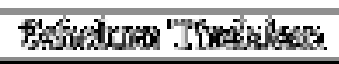 & 暗的 & $\overline{3}$ \\
\hline Pothen & shes & 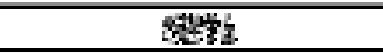 \\
\hline 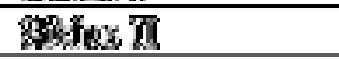 & Shis & 个for \\
\hline
\end{tabular}

Berdasarkan Tabel 1 dapat diketahui bahwa, pada siklus I rata-rata kemampuan pemecahan masalah sebesar 70,28 sudah diatas kriteria yang ditetapkan yaitu 70 . Akan tetapi, persentase ketuntasan kemampuan pemecahan masalah sebesar $68 \%$ belum mencapai $85 \%$, sehingga pelaksanaan tindakan perlu dilanjutkan pada siklus II. Pada siklus II ternyata hasil penelitian ini telah mencapai kriteria yang telah ditetapkan yaitu rata-rata nilai kemampuan pemecahan masalah mahasiswa mencapai 80,08 dan persentase ketuntasan mahasiswa secara klasikal mencapai $88 \%$. Jadi penelitian tindakan ini telah berhasil mencapai kriteria keberhasilan setelah dilaksanakan dalam dua siklus.

Pada saat observasi awal, data ketuntasan belajar mahasiswa menunjukkan 16 mahasiswa (64\%) belum tuntas dan 9 mahasiswa (36\%) sudah tuntas dengan ratarata kemampuan pemecahan masalah klasikal sebesar 61,08. Berdasarkan hasi observasi awal, ditemukan beberapa masalah dalam proses pembelajaran sebagai berikut.

1. Soal-soal yang diberikan dosen pada saat perkuliahan bersifat close problem. Dimana dalam menyelesaikan permasalahan statistik tertutup ini, prosedur yang digunakannya sudah hampir bisa dikatakan standar alias baku.

2. Masalah-masalah statistik terbuka (open problems) hampir tidak tersentuh, hampir tidak pernah muncul dan disajikan dalam proses pembelajaran statistik di kelas. Akibatnya bila ada permasalahan statistik macam ini, soal atau permasalahan itu dianggap 'salah soal' atau soal yang tidak lengkap. Dan,

3. Kreativitas mahasiswa kurang terlatih dalam menjawab soal. Mahasiswa hanya mengingat prosedur baku saja dalam menyelesaikan suatu masalah, artinya mereka hanya menghafalkan prosedur menjawab seperti biasanya. Padahal dalam mata kuliah statistik, kemampuan pemecahan masalah mahasiswa sangat diperlukan.

Berdasarkan permasalahan tersebut maka dilakukan tindakan perbaikan dengan mengimplementasikan pendekatan open ended problem untuk meningkatkan kemampuan pemecahan masalah statistik.

Berdasarkan data penelitian pada siklus I dengan mengimplementasikan open ended problem pada mata kuliah statistik diperoleh data yang menunjukkan peningkatan kemampuan pemecahan masalah dan ketuntasan belajar statistik mahasiswa MFB E semester VI STIPAR Triatma Jaya tahun pelajaran 2016/2017. Pada siklus I terdapat beberapa kendala yang ditemukan. Hal tersebut mengakibatkan belum tercapainya target ketuntasan belajar statistik.

Berdasarkan hasil refleksi pada siklus I ditemukan beberapa kendala sebagai berikut.

1. Mahasiswa masih belum terbiasa dengan permasalahan terbuka, sehingga mahasiswa kurang terlatih 
dalam menjawab soal. Hal ini terlihat dari adanya beberapa mahasiswa yang mengalami kesulitan dalam merespon permasalahan yang diberikan.

2. Mahasiswa kurang percaya diri dalam mengembangkan kreativitas mereka dalam menjawab soal. Hal ini terlihat dari adanya beberapa jawaban yang mirip dengan teman sebangkunya. Dan,

3. Mahasiswa yang memiliki kemampuan tinggi merasa ragu atau mencemaskan jawaban mereka.

Dari data ketuntasan belajar menunjukkan $68 \%$ serta temuan-temuan pada siklus I maka diadakan perbaikan pembelajaran pada siklus II. Perbaikan dilakukan untuk meningkatkan kemampuan pemecahan masalah mahasiswa serta pengelolaan kelas. Pada siklus II, perbaikan dilakukan dengan kegiatan sebagai berikut.

1. Soal yang diberikan dibuat sedemikian rupa sehingga menjadi lebih mudah dipahami. Kemudian dosen juga menjelaskan secara lebih mendetail tentang langkah-langkah dalam mengerjakan permasalah terbuka (open ended problem). Dan,

2. Meyakinkan mahasiswa bahwa tidak ada jawaban salah. Hal ini karena soal yang diberikan adalah soal terbuka, sehingga memiliki banyak penyelesaian.

Setelah dilakukan perbaikan terhadap proses pembelajaran pada siklus II, data kemampuan pemecahan masalah mahasiswa pada mata kuliah statistik menunjukkan peningkatan. Rata-rata kemampuan pemecahan masalah mahasiswa pada siklus II meningkat menjadi 80,08 dan ketuntasan belajar meningkat menjadi $88 \%$.

Perbaikan pembelajaran mengacu pada pendekatan pembelajaran yang diterapkan yaitu open ended problem. Pembelajaran dengan menggunakan pendekatan open ended problem memberikan ruang yang cukup bagi mahasiswa untuk mengeksplorasi permasalahan sesuai kemampuan, bakat, dan minatnya, sehingga mahasiswa yang memiliki kemampuan yang lebih tinggi dapat berpartisipasi dalam berbagai kegiatan pembelajaran, dan mahasiswa dengan kemampuan lebih rendah masih dapat menikmati kegiatan pembelajaran sesuai dengan kemampuannya. Tujuan dari pembelajaran open ended problem adalah untuk membantu mengembangkan kegiatan kreatif dan pola pikir matematik mahasiswa melalui problem solving secara simultan. Dengan kata lain kegiatan kreatif dan pola pikir matematis mahasiswa harus dikembangkan semaksimal mungkin sesuai dengan kemampuan setiap mahasiswa agar aktivitas kelas yang penuh ide-ide matematika memacu kemampuan pemecahan masalah mahasiswa.

Hasil penelitian ini didukung oleh beberapa penelitian sebelumnya yang relevan. Pertama, penelitian yang dilakukan Ariani, Desi (2014) yang berjudul "Pengaruh Implementasi OpenEnded Problem Dalam Pembelajaran Matematika Terhadap Kemampuan Pemecahan Masalah dengan Pengendalian Kemampuan Penalaran Abstrak" mendapatkan hasil bahwa terdapat perbedaan kemampuan pemecahan masalah yang signifikan antara siswa yang mengikuti pembelajaran dengan open-ended problem dan siswa yang mengikuti pembelajaran dengan closed-ended problem, terdapat perbedaan kemampuan pemecahan masalah yang signifikan antara siswa yang mengikuti pembelajaran dengan open-ended problem dan siswa yang mengikuti pembelajaran dengan closed-ended problem setelah kemampuan penalaran abstrak dikendalikan, dan kontribusi kemampuan penalaran abstrak terhadap kemampuan pemecahan masalah sebesar $72 \%$.

Kedua, penelitian yang dilakukan oleh Lambertus (2013) yang berjudul "Penerapan Pendekatan Open-Ended Untuk Meningkatkan Kemampuan Berpikir Kreatif Matematik Siswa SMP” 
menunjukkan hasil bahwa terdapat peningkatan kemampuan berpikir kreatif matematik siswa yang signifikan pada kelas yang pembelajarannya menggunakan pendekatan open-ended, dengan peningkatan sebesar 0,56 , sehingga memiliki klasifikasi sedang. Sedangkan kelas yang pembelajarannya menggunakan pendekatan konvensional, peningkatannya sebesar 0,28 , sehingga memiliki klasifikasi rendah. (2) Peningkatan kemampuan berpikir kreatif matematik siswa yang diajar dengan menggunakan pendekatan open-ended lebih baik secara signifikan dari pada siswa yang diajar dengan menggunakan pendekatan konvensional.

Ketiga, penelitian yang dilakukan oleh Vivi, Nur Koryah dan Idris Harta (2015) yang berjudul "Pengaruh Open-Ended terhadap Prestasi Belajar, Berpikir Kritis dan Kepercayaan Diri Siswa SMP” menunjukkan hasil bahwa (1) ada pengaruh pendekatan open-ended terhadap prestasi belajar matematika, kemampuan berpikir kritis, dan kepercayaan diri siswa SMPN di Kecamatan Kebumen; (2) tidak terdapat pengaruh sekolah serta tidak terdapat interaksi antara pendekatan open-ended dan sekolah terhadap prestasi belajar matematika, kemampuan berpikir kritis, dan kepercayaan diri siswa SMP.

Selain itu, hasil penelitian ini didukung oleh pendapat Becker dan Shimada (Livne, Livne, \& Wight, 2008), yang menyatakan bahwa penggunaan soal terbuka dapat menstimulasi kreativitas, kemampuan berpikir original, dan inovasi dalam statistik. Dalam pembelajaran statistik sangat diperlukan kemampuan dalam pemecahan masalah. Saad \& Ghani (2008) mengemukakan bahwa pemecahan masalah adalah suatu proses terencana yang perlu dilaksanakan agar memperoleh penyelesaian tertentu dari sebuah masalah yang mungkin tidak didapat dengan segera.

Pendekatan Open Ended Problem menurut Suherman, dkk (2003:132) memiliki beberapa keunggulan antara lain: (1) mahasiswa berpartisipasi lebih aktif dalam pembelajaran dan sering mengekspresikan idenya; (2) mahasiswa memiliki kesempatan lebih banyak dalam memanfaatkan pengetahuan dan keterampilan matematik secara komprehensif; (3) mahasiswa dengan kemapuan matematika rendah dapat merespon permasalahan dengan cara mereka sendiri; (4) mahasiswa secara intrinsik termotivasi untuk memberikan bukti atau penjelasan; (5) mahasiswa memiliki pengalaman banyak untuk menemukan sesuatu dalam menjawab permasalahan.

Bingolbali (2011) menyatakan bahwa masalah yang mengundang lebih dari satu jawaban benar atau bersifat open-ended problem mampu meningkatkan aktivitas siswa saat pembelajaran. Secara tidak langsung, ini akan meningkatkan kemampuan komunikasi siswa. Ketika siswa mampu mengkomunikasikan ide-ide matematisnya, itu berarti ia sudah memahami konsep matematika sepenuhnya.

Menurut Shimada \& Becker (Murni, 2013) pendekatan open-ended problem memberikan kesempatan kepada mahasiswa untuk menginvestigasi berbagai strategi dan cara yang diyakininya sesuai dengan mengelaborasi permasalahan. Tujuannya agar kemampuan berpikir mahasiswa dapat berkembang secara maksimal dan pada saat yang sama kegiatan-kegiatan kreatif dari setiap siswa dapat terkomunikasikan melalui proses belajar mengajar. Pokok pikiran dari pembelajaran dengan open-ended problem yaitu pembelajaran yang membangun kegiatan interaktif pada mahasiswa sehingga mengundang mahasiswa untuk menjawab permasalahan melalui berbagai strategi. Dengan kata lain pembelajaran dengan pendekatan open-ended problem bersifat terbuka.

Pendekatan Open-Ended menjanjikan kepada suatu kesempatan kepada siswa untuk meginvestigasi 
berbagai strategi dan cara yang diyakininya sesuai dengan kemampuan mengelaborasi permasalahan. Tujuannya tiada lain adalah agar kemampuan berpikir matematika siswa dapat berkembang secara maksimal dan pada saat yang sama, kegiatan-kegiatan kreatif dari setiap siswa terkomunikasi melalui proses pembelajaran. Inilah yang menjadi pokok pikiran pembelajaran dengan Open-Ended, yaitu pembelajaran yang membangun kegiatan interaktif antara matematika dan siswa sehingga mengundang siswa untuk menjawab permasalahan melalui berbagai strategi. Dalam pembelajaran dengan pendekatan Open-Ended, siswa diharapkan bukan hanya mendapatkan jawaban tetapi lebih menekankan pada proses pencarian suatu jawaban.

\section{E. SIMPULAN DAN SARAN}

Berdasarkan analisis data dan pembahasan hasil penelitian ini, dapat dikemukakan simpulan sebagai berikut. Pertama, implementasi open ended problem dapat meningkatkan kemampuan pemecahan masalah statistik mahasiswa MFB E semester VI STIPAR Triatma Jaya tahun pelajaran 2016/2017. Pada siklus I nilai rata-rata kemampuan pemecahan masalah mencapai 70,28, sedangkan pada siklus II nilai rata-rata kemampuan pemecahan masalah berhasil ditingkatkan menjadi 80,08. Hasil ini menunjukkan bahwa telah terjadi peningkatan nilai ratarata kemampuan pemecahanmasalah sebesar 9,8 dari siklus I ke siklus II. Kedua, implementasi open ended problem dapat meningkatkan ketuntasan belajar statistik mahasiswa MFB E semester VI STIPAR Triatma Jaya tahun pelajaran 2016/2017. Pada siklus I persentase ketuntasan $68 \%$, sedangkan pada siklus II persentase ketuntasan belajar berhasil ditingkatkan menjadi 88\%. Hasil ini menunjukkan bahwa telah terjadi peningkatan persentase ketuntasan belajar sebesar $20 \%$ dari siklus I ke siklus II.

Berdasarkan temuan-temuan dalam penelitian ini dapat diajukan saran-saran sebagai berikut. Pertama, hendaknya dosen di perguruan tinggi mulai menggunakan pendekatan open ended problem sebagai salah satu alternatif pendekatan pembelajaran untuk meningkatkan kemampuan pemecahan masalah statistik mahasiswa. Kedua, dalam pembelajaran statistik hendaknya dosen lebih memperhatikan proses penyelesaian masalah daripada hasil akhirnya saja. Kemampuan pemecahan masalah setiap mahasiswa berbeda-beda sehingga dosen perlu mengemas permasalahan yang diberikan dengan sebaik mungkin. Ketiga, dalam penerapan pendekatan pembelajaran dengan open ended problem, sebaiknya dikombinasikan dengan pemilihan asesmen otentik yang tepat.

\section{DAFTAR PUSTAKA}

Ariani, D. (2014). Pengaruh Implementasi Open-Ended Problem Dalam Pembelajaran Matematika Terhadap Kemampuan Pemecahan Masalah dengan Pengendalian Kemampuan Penalaran Abstrak. Jurnal Penelitian dan Evaluasi Pendidikan Universitas Pendidikan Ganesha. Volume 4, Nomor 1.

Arthur, L. B. (2008). Problem Solving. U.S.: Wikimedia Foundation, Inc. Tersedia pada: http://en.wikipedia.org/wiki/Pro blem_Solving diakses tanggal 20 Mei 2017.

Bingolbali, E. (2011). Multiple Solutions to Problems in Mathematics Teaching: Do Teachers Really Value Them? Australian Journal of Teacher Education: Vol. 36: Iss. 1, Article 2.

Foshay, R. \& Kirkley, J. (2003). Principles for Teaching Problem Solving. Tersedia: www.plato.com/downloads/pape 
rs/p aper_04.pdf. Diakses tanggal 15 Mei $201 \overline{7}$.

Hino, K. (2007). Toward the problemcentered classroom: trends in mathematical problem solving in Japan. Tersedia pada: http://cimm.ucr.ac.cr/ciaemIngles/ar ticulos/universitario/conocimiento/o ward $\% 20$ the $\% 20$ problemcentered $\%$ 20classroom: $\% 20$ trends $\% 20 \mathrm{in} \% 20$ mathematical\%20problem $\% 20$ solvi ng\%20in\%20Japan*Hino,\%20Keiko $\% 20 *$ Keiko\%20Hino.pdf. Diakses tanggal 15 Mei 2017.

Lambertus, dkk. (2013). Penerapan Pendekatan Open-Ended Untuk Meningkatkan Kemampuan Berpikir Kreatif Matematik Siswa SMP. Jurnal Pendidikan Matematika Universitas Halouleo, Volume 4, Nomor 1.

Matlin, M. W. (2003). Cognition. Fifth Edition. Rosewood Drive, Danvers, MA: John Wiley \& Sons, Inc.

Mudjiman, H. (2007). Manajemen Pelatihan Berbasis Belajar Mandiri. Yogyakarta: Pustaka Pelajar.

Murni. (2013). Open-Ended Approach in Learning to Improve Students Thinking Skills in Banda Aceh. International Jurnal of Independent Research and studies-IJIRS. Vol. 2, No. 2 (April, 2013) 95-101.

National Council of Teachers of Mathematics. (2000). Principles and Standards for School Mathematics. Reston, VA: NCTM

Nohda, N. (2000). A study of "openapproach" method in school mathematics teaching -focusing on mathematical problem solving activities. Tersedia pada: http://www.nku.edu/ sheffield/nohd a.html. Diakses tanggal 15 Mei 2017.
Pehkonen. (1999). Open-Ended Problems: A method for an educational change. Paper presented at the International Symposium on Elementary Maths Teaching (SEMT 99). Prague: Charles University.

Prabawanto, S. (2011). Pengembangan Instrumen Tes Pemecahan Masalah Matematis Siswa Sekolah Menengah Pertama. Paper. UPI Bandung. Tidak diterbitkan.

------. (2013). “Meningkatkan Kemampuan Pemecahan Masalah, Komunikasi, dan SelfEffacy Matematis Mahasiswa Melalui Pembelajaran Dengan Pendekatan Metacogniteve Scaffolding”. Disertasi. UPI Bandung. Tidak diterbitkan.

Saad, N. G. S \& Rajendran N.S (2005). The Sources of Pedagogical Content Knowledge (PCK) Used by Mathematics Teacher During Instructions: A Case Study. Departement of Mathematics. Universiti Pendidikan Sultan Idris.

Santyasa. I. W. (2005). Model Pembelajaran Inovatif Dalam Implementasi Kurikulum. Tersedia pada: http://www.freewebs.com.

Diakses pada tanggal 5 Mei 2016.

Slameto. (2003). Belajar dan Faktorfaktor yang Mempengaruhinya. Jakarta: Rineka Cipta.

Strong, S. G. (2009). How do students experience open-ended math problem? Soutern, CA: High Tech High Graduate School of Education. 
Suherman, E. (2003). Evaluasi

Pembelajaran Matematika.

Bandung: JICA UPI.

Sumarmo, U. (2000). Pengembangan Model Pembelajaran Matematika untuk Meningkatkan Kemampuan Intelektual Tingkat Tinggi Siswa Sekolah Dasar. Laporan Hibah Bersaing. Bandung: FPMIPA IKIP Bandung.

Suparno, P. (1997). Filsafat Konstruktivisme dalam Pendidikan. Yogyakarta: Kanisius.

Usman. (2014). Aktivitas Metakognisi Mahasiswa Calon Guru Matematika dalam Pemecahan Masalah Terbuka. Jurnal Didaktik Matematika. 1(2) 21-29.

Vivi, N. K dan Idris, H. (2015). Pengaruh Open-Ended terhadap Prestasi Belajar, Berpikir Kritis dan Kepercayaan Diri Siswa SMP. Jurnal Pendidikan Matematika. Volume 10, Nomor 1.

Wardhani, S., dkk. (2010). Pembelajaran Kemampuan Pemecahan Masalah Matematika Di SMP. Yogyakarta: PPPРTK.

Winarni, E. S \& Harmini, S. (2011). Matematika untuk PGSD. Bandung: PT Remaja Rosdakarya. 